\title{
Development of Green Coffee Beans Extract Loaded Anti-aging Liposomal Gel
}

\author{
Juhi Desai, Rashmi Mallya* \\ Department of Pharmacognosy and Quality Assurance, SVKM's Dr. Bhanuben Nanavati College of Pharmacy, Mithibai College \\ Campus, Mumbai, Maharashtra, INDIA.
}

\begin{abstract}
Background: Green beans of Coffee arabica L. Family: Rubiacea are rich source of polyphenols that prevents the oxidative damage to the skin. In this study, Liposomes were formulated as drug carrier to enhance the skin permeability of polyphenols for topical administration. Materials and Methods: Extracts of green coffee beans were prepared by varying the ratios of methanol and water. Phytochemical analysis and in vitro antioxidant evaluation was conducted on all the extracts to choose the best extract for further studies. The cytotoxicity potential (MTT assay) and anti-elastase activity of chosen extract was evaluated on L929 cell lines using flow cytometer. The liposomes of the extract was prepared by thin film hydration method and optimized by varying the phosphatidylcholine to cholesterol ratio and gradually increasing the amount of extract. Liposomal formulation was converted into gel using carbopol ${ }^{\circ} 974 \mathrm{P}$ as gelling agent. The prepared liposomal suspension and liposomal gel was evaluated for various formulation parameters. Results: The results of phytochemical analysis, in vitro antioxidant assays and in vitro evaluation on L929 cell lines concluded that $25 \%$ methanolic extract was nontoxic with highest phenolic content and exhibited good antielastase activity. The encapsulation efficiency of chlorogenic acid in the optimized liposomal formulation was $75 \%$. The liposomal gel showed sustained release of the drug upto $12 \mathrm{hr}$ compared to 6-7 hr of conventional formulation. Conclusion: The formulated green coffee bean extract loaded liposomal based gel may serve as potential carrier for antiaging effects.
\end{abstract}

Key words: Green coffee beans (GCB), Chlorogenic acid, Extract, Liposomes, Antioxidant, Antiaging.

\section{INTRODUCTION}

The skin plays vital role in modulating body temperature, perceiving pain and pressure and acts as a crucial barrier against environmental insults and pollution making skin aging very evident. ${ }^{1}$ Long term skin exposure to ultraviolet radiation produces free radicals which induces oxidative stress on skin leading to development of photoaging, sunburn, melanogenesis, immunosuppression and photocarcinogenesis. ${ }^{2}$ Free radicals are extremely reactive oxygen molecules that are engaged in forming cross linkages with collagen molecules leading to loss of skin elasticity. ${ }^{3}$ Aging manifest itself with sagging, thinning, dryness and spotting on the skin. Thus, with a desire of looking young, the antiaging products are in great demand. Antioxidants from herbal origin have gained importance in cosmetic industry. Antioxidants help in repairing and preventing oxidative damage caused by free radicals. The antioxidant activity of herbs is majorly due to the redox properties of phenolic compounds. ${ }^{4}$ Thus, antioxidants are found to be promising in delaying the signs of aging such as wrinkles, age spots and fine lines.

The green coffee (Coffea arabica L, Rubiaceae) beans are rich source of polyphenols such as chlorogenic acid and its related compounds such as caffeic acid, coumaric acid and ferulic acid that prevents the skin from oxidative damage.
Submission Date: 18-04-2021; Revision Date: 02-08-2021; Accepted Date: 10-09-2021

DOI: 10.5530/ijper.55.4.198 Correspondence: Dr. Rashmi Mallya SVKM's Dr. Bhanuben Nanavati College of Pharmacy, V M Road Vile parle (W), Mumbai-400056, Maharashtra, INDIA.

Phone: +919819720372,

Email - rashmi.mallya@ bncp.ac.in

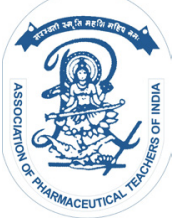

www.ijper.org 
Studies have revealed $C$. arabica extracts are found to posses antibacterial, ${ }^{5}$ antiviral, ${ }^{6}$ anti-inflammatory, ${ }^{7}$ skin wound healing, ${ }^{8}$ reduction of oxidative damage to macromolecules ${ }^{9}$ and suppressive activity of metalloprotienase expression. ${ }^{10}$

Chlorogenic acid, the major polyphenolic compound of green coffe beans has antioxidant and depigmentating property $^{11}$ and it inhibits UV-induced skin damage. ${ }^{12}$ According to the scientific studies, green coffee beans contains a higher amount of chlorogenic acid than roasted coffee beans and other plants. ${ }^{13}$

The delivery of polyphenols through the skin is ineffective due to its limited penetration. Thus the formulation base or penetration enhancers that enhance its penetration is required. ${ }^{14}$ So liposomes were selected as drug carrier as they are ampihilic in nature and hydrophilic molecules can easily be embedded in the concentric bilayers. Liposomes being physiologically similar to the cell membrane are nontoxic in nature. The presence of phospholipids in the liposomes improves topical absorption of the drug from epidermis into the lower layers due to increased adhesion of the drug phoshoplipid complex on the skin. ${ }^{15}$

The aim of the present study is to develop a gel containing green coffee bean extract loaded liposomes to be used as antioxidant cosmetic formulation for antiaging effects.

\section{MATERIALS AND METHODS Materials}

Green coffee arabica $L$. beans were obtained from the local market of Mumbai in August 2019 and was authenticated by Dr. Harshad M. Pandit. Ex-Head and Associate Professor of Botany, Guru Nanak Khalsa College, Mumbai, India. Phosphatidyl choline was purchased from HiMedia Laboratories Pvt Ltd, Cholesterol 99\% was procured from Loba Chemie Pvt Ltd, 2,2-diphenyl-1-picylhydrazyl (DPPH) and Chlorogenic acid was purchased from Otto chemie Pvt Ltd, Mumbai. Gallic acid and Ascorbic acid were procured from SD Fine Chemicals Ltd, Mumbai. All chemicals used in this study were of A. R. grade. Liposomes were produced using Rotary evaporator, Rotaeva, Equitron and UV-Visible Spectrophotometer, Shimadzu 1800 was used for evaluation of liposomes.

\section{Methods}

\section{Extraction Methodology}

The powdered green coffee beans were defatted using petroleum ether $40-60^{\circ} \mathrm{C}(1: 6 \% \mathrm{w} / \mathrm{v})$ for $3 \mathrm{hr}$ in a soxhlet apparatus. The defatted green coffee powder was extracted with different solvents such as water, $25 \%$ methanol, 50\% methanol, 75\% methanol and 100\% methanol for $2 \mathrm{hr}$ using a soxhlet system. The resulting extracts were concentrated in a porcelin dish on electric water bath at $80^{\circ} \mathrm{C}$ to remove the solvent. The prepared extracts were used for qualitative and quantitative analysis.

\section{Total Phenolic Content}

Total phenolic content was determined by FolinCiocalteu reagent method using standard procedure. Gallic acid was used as a standard and total polyphenolic content was expressed as $\mathrm{mg} / \mathrm{g}$ gallic acid equivalent (GAE) from the calibration curve of gallic acid. ${ }^{16}$

\section{Spectral Overlay}

UV spectrometric method was used to determine the presence of chlorogenic acid in the extract. For preparation of standard solutions, $1 \mathrm{mg} / \mathrm{ml}$ of standard chlorogenic acid was dissolved in phosphate buffer and further dilution were prepared to get $10 \mu \mathrm{g} / \mathrm{ml}$ of standard solution.

For sample solution, $25 \%$ of $1 \mathrm{mg} / \mathrm{ml}$ methanolic extract was dissolved in phosphate buffer and further dilution were prepared to get $10 \mu \mathrm{g} / \mathrm{ml}$ of standard solution.

An overlay spectra of both the solution was obtained using UV-Vis spectrophotometry.

\section{Quantification of Chlorogenic acid in each extract}

\section{Standard solution preparation}

The standard chlorogenic acid was dissolved in the solvents such as water, 25\% methanol, 50\% methanol, $75 \%$ methanol and $100 \%$ methanol. In order to reduce the error in preparation procedure, the chlorogenic acid $10 \mathrm{ppm}$ solution was prepared in each above solvent and then corresponding dilution ranging from concentration 2 to $10 \mathrm{ppm}$ was prepared. The linearity plot was made by recording the absorbance at $324 \mathrm{~nm}$ using UV-Vis spectrophotometer.

\section{Sample solution preparation}

For Sample solution preparation, the extracts were dissolved in their respective solvents and $10 \mathrm{ppm}$ solution was made. The absorbance for sample solution was recorded at $324 \mathrm{~nm}$ using UV-Vis spectrophotometer. The obtained absorbance was extrapolated in the linearity plot to find the concentration of chlorogenic acid in each extract. 


\section{Determination of Antioxidant Activities}

\section{DPPH (2,2-diphenyl -1-picrylhydrazyl) antioxidant} assay

Radical scavenging activity of the extracts on DPPH radicals was investigated by following standard method. ${ }^{17}$ Ascorbic acid was used as standard. The experiment was performed in triplicate. The percentage of DPPH radical scavenging activity was plotted against each extract concentration and $\mathrm{IC}_{50}$ was determined.

\section{Nitric Oxide antioxidant assay}

Nitric oxide radical scavenging activity was investigated by use of Griess Illosvoy reaction. ${ }^{18}$ Ascorbic acid was used as standard. The experiment was performed in triplicate. The percentage of nitric oxide radical scavenging activity was plotted against each extract concentration and $\mathrm{IC}_{50}$ was determined.

Percentage Inhibition was for both the antioxidant studies was calculated using below mentioned formula

Scavenging activity was expressed as the inhibition percentage calculated using the following formula:

$$
\% \text { Inhibition }=\frac{\text { Control Abs }- \text { Sample Abs }}{\text { Control Abs }} \times 100
$$

\section{Determination of Cell viability by MTT Assay}

Green coffee beans extract viz 25\% methanolic extract was screened for cytotoxicity study against the L929 cell lines. $200 \mu \mathrm{l}$ of cell suspension was seeded in 96-well plate with cell density (20,000 cells per well), without the test agent. The cells were allowed to grow for about $24 \mathrm{hr}$. An appropriate concentrations of the test agent (25\% methanolic extract) was added, the plate was incubated for $24 \mathrm{hr}$ at $37^{\circ} \mathrm{C}$ in a $5 \% \mathrm{CO}_{2}$ atmosphere and the spent media was removed. MTT reagent was added to a final concentration of $(0.5 \mathrm{mg} / \mathrm{mL})$ of total volume and the plates were incubated for 2-3 hr in dark condition. $100 \mu \mathrm{l}$ of DMSO was added after removal of the MTT reagent and shaken gently. The absorbance was measured at $570 \mathrm{~nm}$ and $630 \mathrm{~nm}$ using a spectrophotometer on an ELISA reader. The $\mathrm{IC}_{50}$ value was determined by using linear regression equation.

Formulae used for the study:

$$
\% \text { Cell Viability }=\frac{\text { Mean Absorbance of Sample Bank }}{\text { Mean Absorbance of Untreated }- \text { Blank }} \times 100
$$

\section{Determination of Anti Elastase activity}

The cells were cultured at the density of $3 \times 10^{5}$ cells $/ 2$ $\mathrm{ml}$ and incubated in a $\mathrm{CO}_{2}$ incubator for $24 \mathrm{hr}$ at $37^{\circ} \mathrm{C}$.
Table 1: Details of test compounds with different concentrations to the respective cell lines used for the study. GC bean represents Green coffee bean extract.

\begin{tabular}{|c|c|c|c|}
\hline Sr.No & Test Compound & $\begin{array}{c}\text { Cell } \\
\text { Line }\end{array}$ & $\begin{array}{c}\text { Concentrations } \\
\text { treated to cells }\end{array}$ \\
\hline 1. & Untreated & L929 & No treatment \\
\hline 2. & Std (Camptothecin) & L929 & $11 \mu \mathrm{M}$ \\
\hline 3. & Blank & - & $\begin{array}{c}\text { Only media without } \\
\text { cells }\end{array}$ \\
\hline 4. & GC bean extract & L929 & $\begin{array}{c}5(12.5,25,50,100,200 \\
\mu \mathrm{g} / \mathrm{ml})\end{array}$ \\
\hline
\end{tabular}

For anti-elastase study, the cells were treated with $250 \mathrm{uM}$ epigallocatechin gallate (EGCG) were used as positive control, the cells treated with $200 \mathrm{ug} / \mathrm{ml}$ of $25 \%$ of methanolic extract was used as test sample (Table 6) and the cells only with culture media were used as negative control and was incubated in $2 \mathrm{ml}$ of culture medium for $24 \mathrm{hr}$. The tubes were centrifuged for five minutes at $300 \mathrm{x}$ g at $25^{\circ} \mathrm{C}$ and the cells were washed with PBS. $0.5 \mathrm{ml}$ of BD Cytofix/Cytoperm solution was added after removal of PBS and tubes were kept undisturbed for $10 \mathrm{~min}$. $0.5 \%$ of bovine serum albumin (BSA) in PBS and $0.1 \%$ sodium azide was used to wash the cells. $20 \mu \mathrm{L}$ of Mouse Anti-Human Neutrophil Elastase/ ELA2 Alexa Fluor ${ }^{\circledR}$ 647-conjugated monoclonal antibody was added, mixed and incubated for $30 \mathrm{~min}$ at room temperature under dark condition. The cells were treated with $0.1 \%$ sodium azide and $0.5 \mathrm{~mL}$ of PBS and analyzed by Flow Cytometry with the excitation and emission of $650 \mathrm{~nm}$ and $668 \mathrm{~nm}$ respectively.

In this study, test compound namely Green coffee bean extract (25\% methanolic extract) and standard Epigallocatechin gallate (EGCG) were used to evaluate its effect on ELA-2 (conjugated mouse anti-human elastase antibody) expression in L929 cell lines.

\section{Preparation of green coffee beans extract loaded liposomes}

The thin film hydration method as described by Bangham et al. ${ }^{19}$ was used to formulate liposomes. The lipid mixture was prepared by dissolving phosphotidylcholine and cholesterol in chloroform and methanol (2:1) in round bottom flask (RBF) and glass beads were added for homogeneous film formation. The RBF was attached to rotary flash evaporator (Roteva, equitron) and allowed to rotate at $80 \mathrm{rpm} / \mathrm{min}$ in a thermostated water bath at $40^{\circ} \mathrm{C}$. The organic solvents were removed by slow application of vaccum leading to homogenous lipid film formation 
Table 2: Optimization of liposomal batches based on drug:lipid ratio and $\mathrm{PC}: \mathrm{CH}$ ratio.

\begin{tabular}{|c|c|c|c|c|}
\hline $\begin{array}{c}\text { Batch } \\
\text { no }\end{array}$ & $\begin{array}{c}\text { Ratio of PC: } \\
\text { CH }\end{array}$ & $\begin{array}{c}\text { Extract } \\
\text { (mg) }\end{array}$ & $\begin{array}{c}\text { Globule } \\
\text { size } \\
\text { (microns) }\end{array}$ & $\begin{array}{c}\text { Chlorogenic } \\
\text { acid } \\
\text { encapsulated } \\
\text { (\%) }\end{array}$ \\
\hline B1 & $1: 0$ & 10 & $2-5$ & 61.52 \\
\hline B2 & $1: 0.1$ & 10 & $2.5-5.5$ & 70.5 \\
\hline B3 & $1: 0.2$ & 10 & $1.5-5$ & 72.8 \\
\hline B4 & $1: 0.5$ & 10 & $2-4$ & 62.00 \\
\hline B5 & $1: 1$ & 10 & $1.5-5$ & 68.00 \\
\hline B6 & $1: 0.1$ & 20 & $1-3$ & 63.2 \\
\hline B7 & $1: 0.2$ & 20 & $0.5-5$ & 74.8 \\
\hline B8 & $1: 0.5$ & 20 & $2-4$ & 54.7 \\
\hline B9 & $1: 1$ & 20 & $1.5-5$ & 68.42 \\
\hline B10 & $1: 0.1$ & 30 & $2.5-5.5$ & 71.33 \\
\hline B11 & $1: 0.2$ & 30 & $2-5$ & 52.34 \\
\hline B12 & $1: 0.5$ & 30 & $0.5-5$ & 56.50 \\
\hline B13 & $1: 1$ & 30 & $1.5-3.5$ & 58.65 \\
\hline
\end{tabular}

PC-Phosphotidylcholine, $\mathrm{CH}$-Cholesterol

on the walls of the flask. The film was allowed to dry for $1 \mathrm{~h}$ for complete removal of organic solvents.

The dried lipid film was hydrated with phosphate buffer ( $\mathrm{pH}$ : 5.4) containing dissolved extract $(25 \%$ of methanolic extract) and then the RBF was rotated at $150 \mathrm{rpm} / \mathrm{min}$ in a thermostated water bath maintained at $46^{\circ} \mathrm{C}$ that is above the transition temperature of lipid. Rotation was continued for $60 \mathrm{~min}$ until homogeneous suspension was obtained. The liposomes produced using this method are large and heterogenous in size, thus bath sonication method was used for $30 \mathrm{~min}$ to downsize the liposomes. The green coffee beans extract based liposomal suspension was allowed to stand for $2 \mathrm{hr}$ at room temperature to ensure complete hydration. The liposomal suspension was stored in amber coloured glass bottle in refrigerator until further use.

\section{Characterization of liposomes}

The following are the parameters for which the prepared liposomes were characterized

\section{Determination of Encapsulation Efficiency}

UV-Vis spectrophotometer was used to estimate the encapsulation efficiency of chlorogenic acid in green coffee bean extract loaded liposomes. The absorbance of chlorogenic acid remaining in the supernatant after centrifugation was measured at $324 \mathrm{~nm}$ using UV-Vis spectrophotometer. Then, the concentration was calculated from calibration plot obtained for standard chlorogenic acid.
Encapsulation efficiency was calculated as follows

$$
\% \text { Encapsulation Efficiency }=\frac{\begin{array}{c}
\text { Total amount of drug added }- \\
\text { Amount of drug detected in supernatant }
\end{array}}{\text { Total amount of drug added }} \times 100
$$

\section{Total amount of drug added}

\section{Optical Microscopy}

A drop of liposomal suspension was placed on a clean glass slide and observed under the power of $45 \mathrm{X}$ and $100 \mathrm{X}$ of the optical microsocope (Motic microsocope).

\section{Determination of Vesicle size, Polydispersibility Index (PDI) and Zeta Potential}

Vesicle size and Polydispersibility Index were analysed by using dynamic light scattering instrument with a computerized inspection system (Malvern particle size analyzer). Freshly prepared liposomal batches were diluted in the ratio of 1:100 with the deionized water. All measurements were done in triplicate at $25 \pm 0.5^{\circ} \mathrm{C}$. Liposomal suspension was diluted with the deionized water and zeta potential was determined using Malvern zetasizer.

\section{Transmission Electron Microscopy (TEM)}

TEM analysis was carried out for optimized drug loaded suspension by transmission electron microscopy (Tecnai T20, 200Kev, FEI). A drop of suspension was placed with the aid of micropipette on the grid. The grid was dried well. The dried grid containing the sample was bombarded with electrons accelerated at $200 \mathrm{KV}$. Then vesicle size and liposomal morphology was visualized by TEM under vaccum (Figure 1).

\section{Preparation of Liposomal Gel}

Green coffee beans extract loaded liposomal gel was prepared by using carbopol ${ }^{\circledR} 974 \mathrm{P}$ gel base. Accurately $0.5 \%$ of carbopol $^{\circledR} 974 \mathrm{P}$ was weighed and kept for hydration in double distilled water cointaining

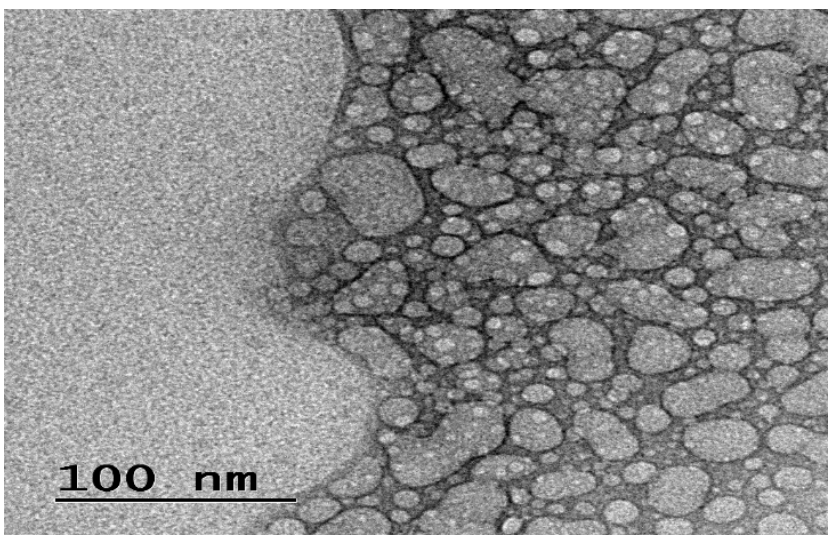

Figure 1: TEM image of green coffee beans loaded liposomes. 
preservatives overnight. Liposomal pellets obtained after centrifugation was dispersed in distilled water by sonication and added to hydrated carbopol solution with stirring. Gelling was induced by neutralization using triethanolamine (TEA). The gel was evaluated for colour, texture (smoothness and greasiness), $\mathrm{pH}$, viscosity, drug content, spreadability and in vitro release drug study.

\section{In vitro drug release study}

The Franz diffusion cells appparatus having receptor compartment capacity of $22 \mathrm{ml}$ and surface area of 3.91 $\mathrm{cm}^{2}$ was used to estimate in vitro drug release Dialysis membrane (molecular weight cut-off 12,000-14,000) which was pre-hydrated by soaking in buffer overnight were mounted on the cells. Phosphate buffer $\mathrm{pH} 5.4$ $\left(37^{\circ} \mathrm{C} \pm 0.5^{\circ} \mathrm{C}\right)$ was used as receptor fluid. Reservoir solution was stirred at $100 \mathrm{rpm} / \mathrm{min}$ using a magnetic bead. $0.5 \mathrm{~g}$ of gel was placed in donor compartment on the membrane. Aliquots were collected at 1, 2, 3, 4, $5,6,7,8,12$ and $24 \mathrm{hr}$ intervals and analyzed by UV-Vis spectrophotometer at $324 \mathrm{~nm} .{ }^{20}$

\section{RESULTS AND DISCUSSION}

\section{Extraction Methodology}

The percentage yields of green coffee arabica $L$. beans extracts is presented in the Table 3. The physical appearance of all the extracts were dark yellow and dark brown in colour. The $25 \%$ of methanolic extract showed the highest percentage yield as $26.54 \pm 0.13$ compared to all other extracts.

\section{Total Phenolic Content}

The Folin-Ciocalteu method was used to estimate the total phenolic content of all the extracts. The TPC

\begin{tabular}{|c|c|c|c|}
\hline Extracts & $\%$ Yield & $\begin{array}{c}\mathrm{TPC}(\mathrm{mg} / \mathrm{g} \\
\text { of GAE) }\end{array}$ & $\begin{array}{l}\text { Chlorogenic } \\
\text { acid content } \\
(\mathrm{mg} / \mathrm{g})\end{array}$ \\
\hline Aqueous extract & $24.42 \pm 0.103$ & $478 \pm 0.34$ & $37.1 \pm 0.24$ \\
\hline $\begin{array}{c}\text { Methanolic } \\
\text { extract }\end{array}$ & $22.26 \pm 0.203$ & $530 \pm 0.96$ & $41.2 \pm 0.35$ \\
\hline $\begin{array}{c}25 \% \text { methanolic } \\
\text { extract }\end{array}$ & $26.54 \pm 0.13$ & $580 \pm 1.52$ & $43.4 \pm 1.25$ \\
\hline $\begin{array}{c}50 \% \text { methanolic } \\
\text { extract }\end{array}$ & $23.02 \pm 0.23$ & $456 \pm 0.13$ & $40.2 \pm 0.31$ \\
\hline $\begin{array}{c}75 \% \text { methanolic } \\
\text { extract }\end{array}$ & $25.30 \pm 0.31$ & $460 \pm 1.15$ & $38.9 \pm 1.54$ \\
\hline
\end{tabular}

of all the extract is expressed in terms of Gallic acid equivalent (The standard curve equation: $y=0.0031+$ $\left.0.3477, r^{2}=0.9953\right)$ mentioned in the Table 1. Amongst all the extracts major phenolic content is estimated in $25 \%$ of methanolic extract.

\section{Spectral Overlay}

\section{Quantification of Chlorogenic acid in each extract}

The amount of chlorogenic acid content present in each extract is mentioned in Table 3 and Figure 2. As per the results the highest amount chlorogenic acid was found to be present in $25 \%$ of methanolic extract.

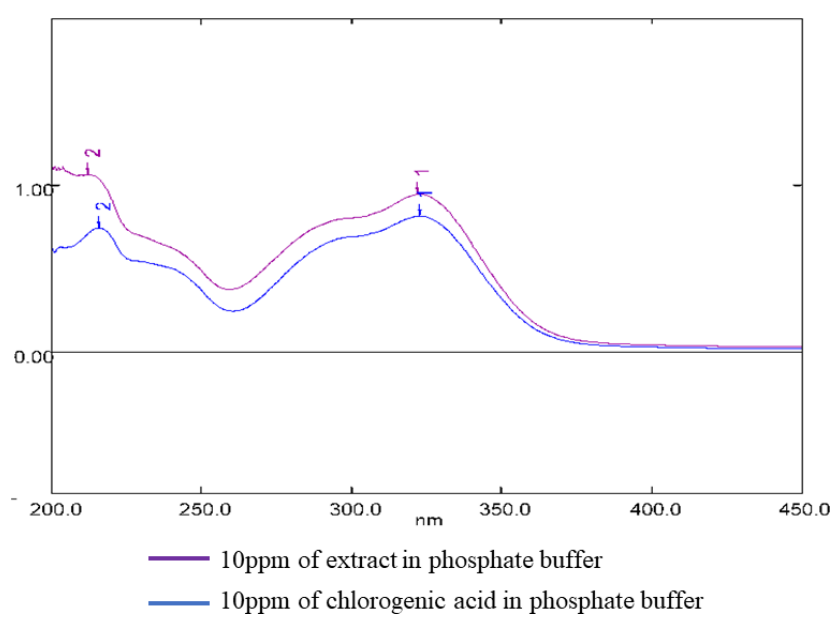

Figure 2: Spectral overlay of standard chlorogenic acid and presence of chlorogenic acid in extract. From Figure 2 (Spectral overlay) confirmed that the $25 \%$ methanolic extract had presence of chlorogenic acid in it.

\section{Determination of Antioxidant Activities}

The extracts exhibited antioxidant activity in concentration-dependent manner. The antioxidant activity of the extract was expressed in terms of $\mathrm{IC}_{50}$. Consolidated results of DPPH assay and Nitric oxide antioxidant assay is mentioned in Table 4.

\begin{tabular}{|c|c|c|}
\hline Extracts & $\begin{array}{c}\mathrm{IC}_{50}(\mu \mathrm{g} / \mathrm{ml}) \mathrm{DPPH} \\
\text { assay }\end{array}$ & $\begin{array}{c}\mathrm{IC}_{50}(\mu \mathrm{g} / \mathrm{ml}) \text { Nitric } \\
\text { oxide assay }\end{array}$ \\
\hline $\begin{array}{l}\text { Ascorbic acid } \\
\text { (Standard) }\end{array}$ & $55.41 \pm 0.12$ & $54.70 \pm 0.08$ \\
\hline Aqueous extract & $230.89 \pm 0.25$ & $234.75 \pm 0.12$ \\
\hline Methanolic extract & $146.52 \pm 0.44$ & $148.34 \pm 0.24$ \\
\hline $\begin{array}{c}25 \% \text { methanolic } \\
\text { extract }\end{array}$ & $143.92 \pm 0.28$ & $145.23 \pm 0.18$ \\
\hline $\begin{array}{l}50 \% \text { methanolic } \\
\text { extract }\end{array}$ & $184.62 \pm 0.20$ & $186.25 \pm 0.13$ \\
\hline $\begin{array}{c}75 \% \text { methanolic } \\
\text { extract }\end{array}$ & $172.43 \pm 0.22$ & $177.62 \pm 0.45$ \\
\hline
\end{tabular}


Table 5: Represents IC I0 $_{50}$ concentration of green coffee bean extract and the standard campthothecin against L929 cell lines.

\begin{tabular}{|c|c|c|}
\hline Sr. no & Test compounds & IC $_{50}(\boldsymbol{\mu g} / \mathbf{m I})$ \\
\hline 1. & Campthothecin & 23 \\
\hline 2. & GC bean extract & 306.38 \\
\hline
\end{tabular}

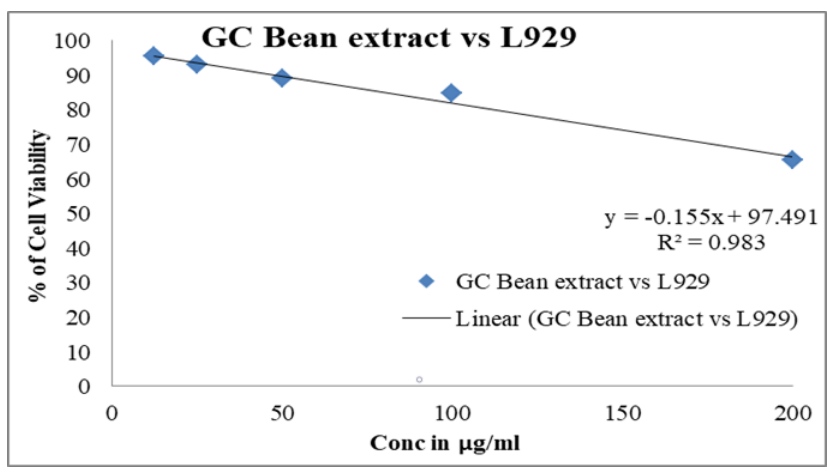

Graph 1: Scatter graph showing the \% cell viablility of L929 cell line against green coffee bean extract and the inhibitory concentration ( $\mathrm{IC}_{50}$ value) observed is $306.38 \mu \mathrm{g} / \mathrm{ml}$.

Based on the results obtained from total phenolic content, quantification of chlorogenic acid and antioxidant assay $25 \%$ methanolic extract was found to contain highest phenolic content, greater quantity of chlorogenic acid and maximal radical scavenging activity compared to other extracts.

\section{Determination of Cell viability by MTT Assay}

Viability assay is an assay that determines the ability of tissues, cells or organs to maintain or recover the state of survival. Cytotoxicity study of the test compound, green coffee bean extract against L929 cell lines in statistical data of cell cytotoxicity study by ELISA reader suggested us that green coffee bean extract showed moderate cytotoxicity potential properties with Inhibitory concentration $\left(\mathrm{IC}_{50}\right.$ ) at $306.38 \mu \mathrm{g} / \mathrm{ml}$ compared to standard drug Camptothecin with $23 \mu \mathrm{g} / \mathrm{ml}$ Table 5 . The observation strongly suggest us that the green coffee bean extract do not have significant cytotoxicity potential with the concentration ranging from $12.5-200 \mu \mathrm{g} / \mathrm{ml}$ respectively with incubation period of 24 hrs at $37^{\circ} \mathrm{C}$ (Graph 1).

\section{Determination of Anti Elastase activity}

The enzyme elastase is capable of breaking down elastin, an insoluble elastic fibrous protein that together with collagen contributes to the mechanical strength of the connective tissue. Several studies have suggested that both skin aging and anti-wrinkle effects significantly corresponds to reduced elastase activity. Thus antielastase studies was carried out to confirm the utility of green coffee bean extract as a anti-aging agent. In this study, test compound namely Green coffee bean extract and Std, EGCG were used to evaluate its effect on ELA-2 (conjugated mouse anti-human Elastase antibody) expression in L929 cell line. The concentrations of the compounds used in the experiment were as follows:

The given test compound GC bean extract suppressed the ELA-2 expression in L929 cell line. The relative mean fluorescence intensity values of ELA-2 were almost similarly decreased in std, Epigallocatechin gallate and test compound green coffee bean extract. (Table 7; Figure 3 and Histogram 1). Hence, GC bean can be considered as a good anti elastase agent.

\section{Preparation of green coffee beans extract loaded liposomes}

In this study thin film hydration method was used to formulate liposomes. The reason for selecting this

Table 6: Represents the concentration of green

coffee bean extract and standard compound used to determine antiaging potential against L929 cell lines.

\begin{tabular}{|c|c|c|c|}
\hline Sr.No & Test Compounds & $\begin{array}{c}\text { Cell } \\
\text { Line }\end{array}$ & Concentrations \\
\hline 1 & Cell Control/Untreated & L929 & No treatment \\
\hline 2 & STD (EGCG) & L929 & $250 \mathrm{uM}$ \\
\hline 3 & GC bean extract & L929 & $200 \mathrm{ug} / \mathrm{ml}$ \\
\hline
\end{tabular}

Effect of the GC bean extract on ELA-2 expression in L929 cell line

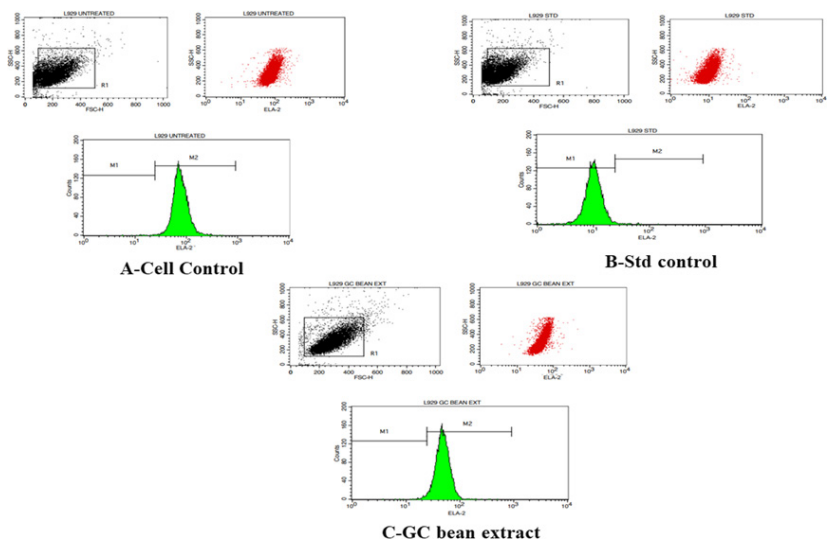

Figure 3: Histograms depicting the ELA-2 expression observed in cell control (A), Std Control (B) and GC bean extract treated L929 cell line with the incubation period of $24 \mathrm{hrs}(\mathrm{C})$. Analysis was done by using BD FACS Calibur, Cell Quest Pro software (Version: 6.0). Histograms of the gated L929 singlets distinguish cells at the M1 and M2 phases. (Here M1 refers to Positive expression/region and M2 refers to the Negative expression/region). 
Relative mean flourescence intensity values of ELA-2 in L929 cell line treated with test compound GC bean
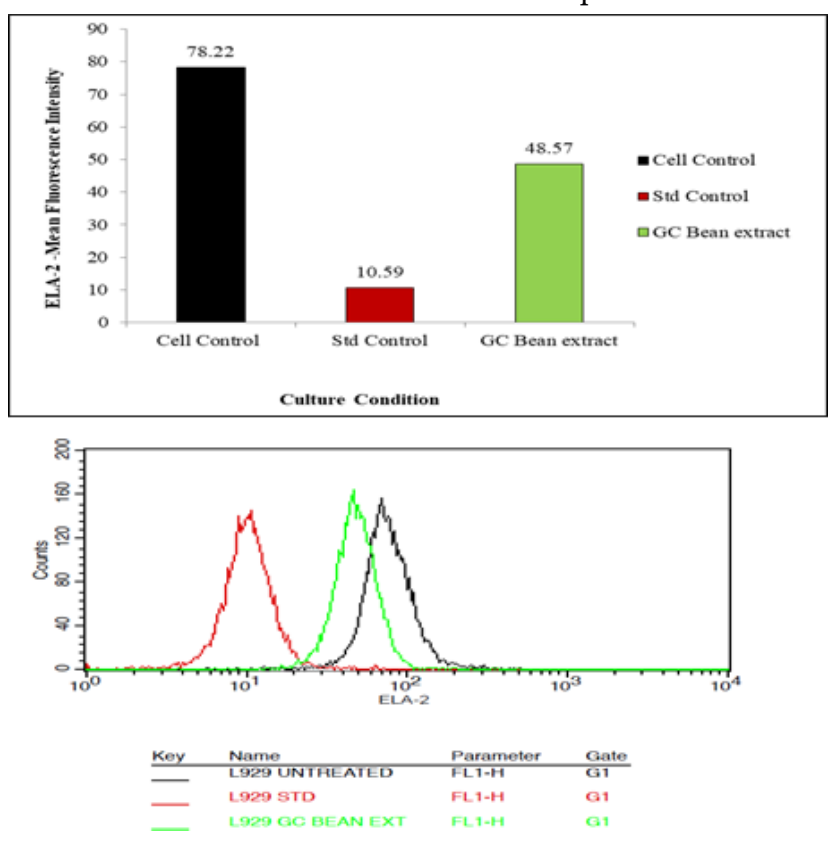

Histogram 1: Overlay histogram of GC bean extract.

\begin{tabular}{|c|c|}
\hline Parameters & $\begin{array}{l}\text { ELA-2 Relative Mean } \\
\text { Fluorescence Intensity }\end{array}$ \\
\hline Cell Control & 78.22 \\
\hline Std Control & 10.59 \\
\hline Green Coffee Bean Extract & 48.57 \\
\hline
\end{tabular}

method is as it is simplest method for preparing multilamellar vesicles and is capable of loading higher mass of hydrophilic molecule such as chlorogenic acid compared to unilamellar vesicles. Thin film hydration method was found to give $75 \%$ of encapsulation efficiency for chlorogenic acid present in the extract Table 2. Thus, this method was used for preparation of the liposomes.

\section{Characterization of liposomes Optical Microscopy}

Multilamellar vesicle was clearly observed (Figure 4). Microscopic observation were used to evaluate the shape and size of the vesicles was noted for all the prepared batches.
Determination of Polydispersibility Index (PDI), Zeta Potential and Vesicle size

PDI basically appears for size distribution of the vesicles in a given sample. The numerical value of PDI starts with 0.0 (perfectly uniform particle size) to 1.1 (highly polydisperse particle size). In case of lipid based carrier systems such as liposomes and nanoliposomes a size of 0.3 and below is acceptable as it indicates homogeneous population of phospholipid vesicles. ${ }^{21}$

Zeta potential is a significant characterization technique which is employed to understand physical stability of the particles. A value from $-30 \mathrm{mV}$ to $+30 \mathrm{mV}$ is generally considered to have sufficient repulsive force to attain better physical collidal stability. ${ }^{22}$

The thin film hydration method gives large and heterogenous multilamellar vesicles. Size analysis of the produced liposomes revealed $\mathrm{z}$ - average (d.nm) size of $864.2 \mathrm{~nm}$, PDI of 0.375 and Zeta Potential of -12.4 with good entrapment efficiency.

\section{Transmission Electron Microscopy (TEM)}

Morphological analysis of these liposomes by TEM showed spherical shaped liposomes.

\section{Preparation of Liposomal Gel}

Liposomal dispersion was simply mixed with the polymer to give corresponding gels. Liposomal gel formulation is advantageous as the fusion of the vesicles can effectively be avoided or minimized as the polymer serves as spacer between the liposomes. Thereby, the vesicle size is not affected because it is a controlled polymer/liposome interaction process. Liposomal based cream formulation was not chosen as stability issues are reported in emulsion-based products due to

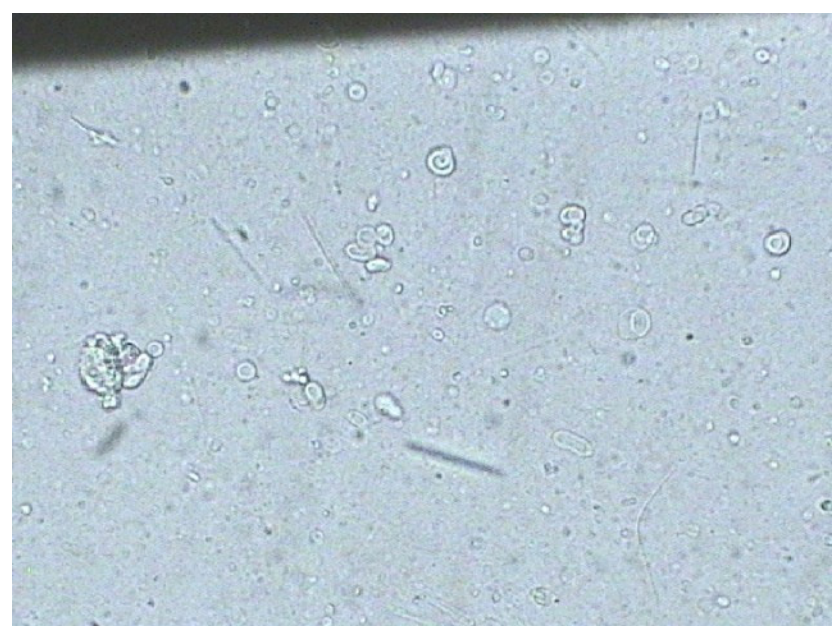

Figure 4: Shows large multilamellar vesicles visible under 100X magnification. 
presence of surfactant and excess oil which may interact with vesicles. Various properties such as viscosity can easily be controlled by varying the concentration of the polymer or changing the polymer type. Thus liposomal gels were prepared as they circumvent the stability issue, provide controlled release, easy to prepare and have aesthetic appeal as skin care cosmetics. ${ }^{23}$

The prepared lipogels were pale yellow in color and opaque. $0.5 \% \mathrm{w} / \mathrm{w}$ of $\mathrm{carbopo}^{\circledR} 974 \mathrm{P}$ was found have good consistency and smooth appearance devoid of any aggregation. The drug content for the liposomal gel was found to be $94.16 \pm 1.3$ with viscosity of gel in the range of $13,500 \mathrm{cps}$ to $16,500 \mathrm{cps}$ and spreadability around $7-8$ g.cm/s.

\section{In vitro drug release profile}

The outermost layer of the skin is stratum corneum and is mainly composed of protein keratin and lipids. The intercellular lipids plays a vital role in controlling the percutaneous absorption. The intercellular lipids may interact with the phospholipids present in the liposomes and thereby cause swelling of the lipids without altering the multiple bilayer structure of the stratum corneum. These swollen lipids causes drug to accumulate and forms an intracutaneous depot. Although the mechanism of topically applied liposomes is not fully understood, but lipid composition, surface charge and liposomal lamellarity primarily plays an important role in drug disposition. Studies has also revealed topical delivery is also influenced by size of liposomes. ${ }^{24}$ The in vitro drug release was performed using dialysis membrane. The in vitro =release study of liposomal gel has shown sustained release effect upto $12 \mathrm{hr}$ compared to 7-8 hr of conventional gel Graph 2.

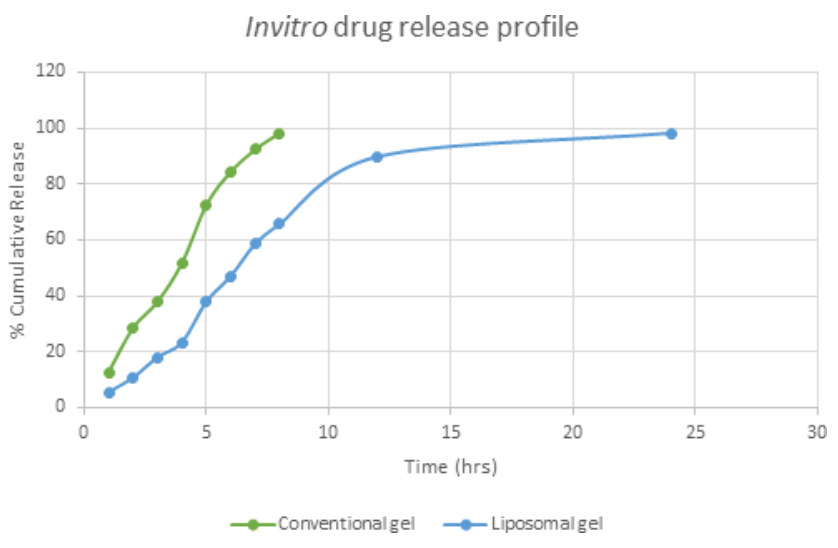

Graph 2: Comparative in vitro drug release through dialysis membrane.

\section{CONCLUSION}

Green Coffee arabica beans extracts were screened for total phenolic content, quantification of chlorogenic acid and antioxidant assay. Based on the results obtained from these studies $25 \%$ of methanolic extract was chosen to be incorporated into liposomes as it had shown highest phenolic content, greater quantity of chlorogenic acid and better antioxidant activity. Before incorporating the extract into the liposomes it was screened for MTT and antielastase assay. Based on MTT asssay the extract had no cell cytotoxicity potential and as per antielastase assay the extract had antielastase activity. Thus the extract can be utilized to formulate antiaging liposomes. The multilamellar vesicles were prepared using thin film hydration method. The prepared liposomes had good encapsulation efficiency and better physical stability. The extract based liposomal suspension was formulated into liposomal gel. As per in vitro drug release study the liposomal gel has shown prolonged release effect upto $12 \mathrm{hr}$ compared to the conventional gel. Hence green coffee beans extract loaded liposomes can be considered to be an effective carrier for the topical delivery with antiaging potential.

\section{ACKNOWLEDGEMENT}

The authors are thankful to Stellixir Biotechechnology, Bengaluru, Karnataka for their help in completing MTT assay and Anti-elastase assay studies, we also thank Sprint testing solutions, Mumbai for TEM imaging and our college SVKM's Dr. Bhanuben Nanavati College of Pharmacy for providing the best facilities to conduct this study.

\section{CONFLICT OF INTEREST}

The authors declare no conflict of interest.

\section{ABBREVIATIONS:}

TPC: Total phenolic content; DPPH: 2, 2-diphenyl -1-picrylhydrazyl; GAE: Gallic acid equivalent; GC: Green Coffee; GCB: Green coffee beans; ELA-2 (Conjugated mouse anti-human Elastase antibody): Neutrophil Elastase; EGCG: Epigallocatechin gallate; PC: Phosphatidylcholine; CH: Cholesterol; RBF: Round Bottom Flask; TEM: Transmission Electron Microscopy; MTT: 3-(4,5-diemthylthiazol-2-yl)-2,5diphenyl tetrazolium bromide; PDI: Polydispersibility Index; IC $_{50}$ : Half-Maximal Inhibitory Concentration. 


\section{REFERENCES}

1. Varshneya A, Ravikumar P. Liposomes as carrier in skin ageing. Int J Curr Pharm Res. 2014 Jul;6(3):1-7.

2. Afaq $F$, Mukhtar $\mathrm{H}$. Effects of solar radiation on cutaneous detoxification pathways. J Photochem Photobiol B. 2001 Oct;63(1-3):61-9. doi: 10.1016/ s1011-1344(01)00217-2, PMID 11684452.

3. Aziz J, Shezali H, Radzi Z, Yahya NA, Abu Kassim NH, Czernuszka J, Rahman MT. Molecular mechanisms of stress-responsive changes in collagen and elastin networks in skin. Skin Pharmacol Physiol. 2016;29(4):190203. doi: 10.1159/000447017, PMID 27434176.

4. Liang T, Yue W, Li Q. Comparison of the phenolic content and antioxidant activities of Apocynum venetum L. (Luo-bu-Ma) and two of its alternative species. Int J Mol Sci. 2010 Nov 9;11(11):4452-64. doi: 10.3390/ijms11114452, PMID 21151449.

5. Almeida AA, Farah A, Silva DA, Nunan EA, Glória MB. Antibacterial activity of coffee extracts and selected coffee chemical compounds against enterobacteria. J Agric Food Chem. 2006 Nov 15;54(23):8738-43. doi: 10.1021/jf0617317, PMID 17090115.

6. Utsunomiya $\mathrm{H}$, Ichinose $\mathrm{M}$, Uozaki $\mathrm{M}$, Tsujimoto $\mathrm{K}$, Yamasaki $\mathrm{H}$, Koyama AH. Antiviral activities of coffee extracts in vitro. Food Chem Toxicol. 2008 Jun;46(6):1919-24. doi: 10.1016/j.fct.2008.01.031, PMID 18314244.

7. dos Santos MD, Almeida MC, Lopes NP, de Souza GE. Evaluation of the antiinflammatory, analgesic and antipyretic activities of the natural polyphenol chlorogenic acid. Biol Pharm Bull. 2006 Nov;29(11):2236-40. doi: 10.1248/ bpb.29.2236, PMID 17077520.

8. Affonso RC, Voytena AP, Fanan S, Pitz H, Coelho DS, Horstmann AL, Pereira A, Uarrota VG, Hillmann MC, Varela LA, Ribeiro-do-Valle RM, Maraschin M. Phytochemical composition, antioxidant activity, and the effect of the aqueous extract of coffee (Coffea arabica L.) bean residual press cake on the skin wound healing. Oxid Med Cell Longev. 2016;2016:1923754. doi: 10.1155/2016/1923754.

9. Hoelzl C, Knasmüller S, Wagner KH, Elbling L, Huber W, Kager N, Ferk F, Ehrlich V, Nersesyan A, Neubauer O, Desmarchelier A, Marin-Kuan M, Delatour T, Verguet C, Bezençon C, Besson A, Grathwohl D, Simic T, Kundi M, Schilter B, Cavin C. Instant coffee with high chlorogenic acid levels protects humans against oxidative damage of macromolecules. Mol Nutr Food Res. 2010 Dec;54(12):1722-33. doi: 10.1002/mnfr.201000048, PMID 20589860.

10. Chiang HM, Lin TJ, Chiu CY, Chang CW, Hsu KC, Fan PC, Wen KC. Coffea arabica extract and its constituents prevent photoaging by suppressing MMPs expression and MAP kinase pathway. Food Chem Toxicol. 2011 Jan;49(1):309-18. doi: 10.1016/j.fct.2010.10.034, PMID 21056074.

11. LiHR, Habasi M, Xie LZ, Aisa HA. Effect of chlorogenic acid on melanogenesis of B16 melanoma cells. Molecules. 2014 Aug 25;19(9):12940-8. doi: 10.3390/molecules190912940, PMID 25157464.
12. Kitagawa S, Yoshii K, Morita SY, Teraoka R. Efficient topical delivery of chlorogenic acid by an oil-in-water microemulsion to protect skin against UV-induced damage. Chem Pharm Bull (Tokyo). 2011;59(6):793-6. doi: 10.1248/cpb.59.793, PMID 21628922.

13. Nitthikan N, Leelapornpisid P, Natakankitkul S, Chaiyana W, Mueller M, Viernstein $\mathrm{H}$, Kiattisin K. Improvement of stability and transdermal delivery of bioactive compounds in green robusta coffee beans extract loaded nanostructured lipid carriers. J Nanotechnol. 2018 May;2018:1-12. doi: 10.1155/2018/7865024.

14. Nichols JA, Katiyar SK. Skin photoprotection by natural polyphenols: antiinflammatory, antioxidant and DNA repair mechanisms. Arch Dermatol Res. 2010 Mar;302(2):71-83. doi: 10.1007/s00403-009-1001-3, PMID 19898857.

15. Rahimpour Y, Hamishehkar H. Liposomes in cosmeceutics. Expert Opin Drug Deliv. 2012 Apr;9(4):443-55. doi: 10.1517/17425247.2012.666968, PMID 22413847.

16. Geremu M, Tola YB, Sualeh A. Extraction and determination of total polyphenols and antioxidant capacity of red coffee (Coffea arabica L.) pulp of wet processing plants. Chem Biol Technol Agric. 2016 Sep;3(1):1-6.

17. Shirwaikar A, Prabhu KS, Punitha IS. In vitro antioxidant studies of Sphaeranthus indicus (Linn). Indian J Exp Biol. 2006 Dec;44(12):993-6. PMID 17176673.

18. Parul R, Kundu SK, Saha P. In vitro. Nitric oxide scavenging activity of methanol extracts of three Bangladeshi medicinal plants. J Pharm Innov. 2013 Feb;1(12):83-8.

19. Laouini A, Jaafar-Maalej C, Limayem-Blouza I, Sfar S, Charcosset C, Fessi H. Preparation, characterization and applications of liposomes: state of the art. J Coll Sci Biotechnol. 2012 Dec;1(2):147-68. doi: 10.1166/jcsb.2012.1020.

20. Varshneya A, Ravikumar P. Formulation and Characterization of Rutin trihydrate liposomes for Topical Delivery. Int J Pharmacol Res. 2015 Jan;7(3):29-37.

21. Danaei M, Dehghankhold M, Ataei S, Hasanzadeh Davarani F, Javanmard R, Dokhani A, Khorasani S, Mozafari MR. Impact of particle size and polydispersity index on the clinical applications of lipidic nanocarrier systems. Pharmaceutics. 2018 May 18;10(2):E57. doi: 10.3390/ pharmaceutics10020057, PMID 29783687.

22. Joseph E, Singhvi G. Multifunctional nanocrystals for cancer therapy: a potential nanocarrier. Nanomaterial Drug Deliv Ther. 2019 Mar:91-116.

23. Sharma R, Walker RB, Pathak K. Evaluation of the Kinetics and Mechanism of Drug Release from econazole nitrate Nanosponge Loaded Carbapol Hydrogel. Ind J Pharm Res Edu. 2011 Jan;45(1):25-31.

24. Verma DD, Verma S, Blume G, Fahr A. Particle size of liposomes influences dermal delivery of substances into skin. Int J Pharm. 2003 Jun 4;258(12):141-51. doi: 10.1016/s0378-5173(03)00183-2, PMID 12753761. 
PICTORIAL ABSTRACT

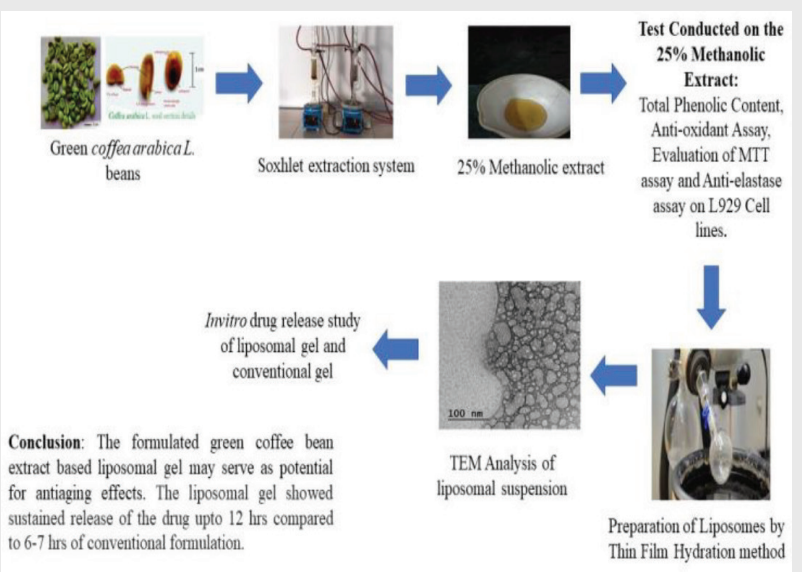

\section{About Authors}

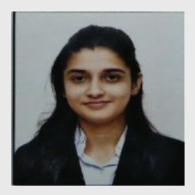

Ms. Juhi Desai (Quality Assurance, SVKM's Dr. Bhanuben Nanavati college of pharmacy Gate no: 1 Mithibai college campus, V M Road, Vile parle- west, Mumbai-56, India.

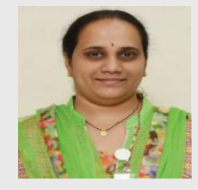

Dr. Rashmi Mallya* (corresponding author) Assistant professor, Department of pharmacognosy, SVKM's Dr. Bhanuben Nanavati College of Pharmacy Gate no: 1 Mithibai college campus, $\mathrm{V}$ M Road, Vile parle- West, Mumbai-56, India.

\section{SUMMARY}

Aging of skin is an inevitable process. The skin aging is characterized by loss of elasticity, wrinkling, laxity, sagging and rough texture of the skin. The process of aging causes structural and functional changes in the cutaneous cells as well as extracellular matrix components such as elastin and collagens. One cannot stop the aging process but, obviously, one can delay the sign's of aging by application of antiaging agents. The topical route of drug delivery is well known in the field of pharamaceutics. Over the centuries, the topical drug delivery system has been investigated to deliver diverse range of therapeutic agents. However, the stratum corneum of the skin sets the rate limiting barrier for the transport of drugs via topical route. To overcome these challenges, liposomes were selected as drug carrier as they are ampihilic in nature and hydrophilic molecules can easily be embedded in the concentric bilayers. Liposomes being physiologically similar to the cell membrane they are nontoxic in nature. The phospholipids present in liposomes allows increased adhesion of the complex of bioactive compound to the skin surface and improves topical absorption from epidermis into the deepest layers of the skin. In the Present study, the developed green coffee arabica $L$. beans based liposomal gel may be used as antioxidant cosmetic formulation for antiaging effects.

Cite this article: Desai J, Mallya R. Development of Green Coffee Beans Extract Loaded Anti-aging Liposomal Gel. Indian J of Pharmaceutical Education and Research. 2021;55(4):979-88. 